\title{
Chemical Composition and Biological Activities of the Black Sea Algae Polysiphonia denudata (Dillw.) Kutz. and Polysiphonia denudata f. fragilis (Sperk) Woronich
}

Salvatore De Rosa ${ }^{\mathrm{a}, *}$, Zornitsa Kamenarska ${ }^{\mathrm{b}}$, Vassya Bankova ${ }^{\mathrm{b}}, \mathrm{Kamen}_{\text {Stefanov }}^{\mathrm{b}}$, Stefka Dimitrova-Konaklieva ${ }^{\mathrm{c}}$, Hristo Najdenski ${ }^{\mathrm{d}}$, Iva Tzevtkova ${ }^{\mathrm{d}}$ and Simeon Popov ${ }^{\mathrm{b}}$

a Istituto di Chimica Biomolecolare, CNR, Via Campi Flegrei, 34, 80078 Pozzuoli, Napoli, Italy. E-mail: sderosa@icmib.na.cnr.it

${ }^{b}$ Institute of Organic Chemistry with Centre of Phytochemistry, Bulgarian Academy of Sciences, Sofia 1113, Bulgaria

c Medical University, Faculty of Pharmacy, Sofia 1000, Bulgaria

d Institute of Microbiology, Bulgarian Academy of Sciences, Sofia 1113, Bulgaria

* Author for correspondence and reprint requests

Z. Naturforsch. 56c, 1008-1014 (2001); received July 3/September 14, 2001

Polysiphonia denudata, Sterols, Volatiles

The two investigated algae had almost identical sterol composition, but there were significant differences in the composition of the polar components and especially in the composition of the volatiles. P. denudata $f$. fragilis extracts possessed a stronger biological activity (antibacterial, antifungal and toxicity against Artemia salina). Despite the minute morphological differences between the two algae, we recommend $P$. denudata $f$. fragilis to be regarded as $P$. denudata subsp. fragilis.

\section{Introduction}

Polysiphonia denudata and its form $P$. denudata f. fragilis are red algae (Rhodophyta) and belong to family Rhodomelaceae, order Ceramiales, class Rhodophyceae. P. denudata is a widely spread species, while $P$. denudata $f$. fragilis is endemic for the Black Sea.

Despite their wide distribution, there is a limited data on the chemical composition of the algae from genus Polysiphonia. Until now, mainly polysaccharides (Usov and Ivanova, 1987), lipids (Kamenarska et al., 2001; Kurbanov et al., 1997) and sterols (Elyakov and Stonic, 1988; Al Easa et al., 1995) have been investigated. A number of brominated phenols were identified in the red algae from family Rhodomelaceae (Faulkner, 2001; Flodin and Whitfield, 2000). Only fatty acids of $P$. denudata were reported (Kamenarska et al., 2001; Kurbanov et al., 1997). There are no investigations, concerning the chemical composition and biological activity of $P$. denudata $f$. fragilis. Recently, we found a significant antiviral activity in extracts from $P$. denudata from the Black Sea (Serkedjieva et al., 2000). So it is of interest to investigate the chemical composition and biological activity of the two algae. Comparisons of taxonomic significance could also be made.

\section{Materials and Methods}

\section{Collection of the samples}

Sample of $P$ denudata was collected in May, near the town of Ahtopol at the Black Sea.

Sample of $P$. denudata $f$. fragilis was collected in May, near the village of Varvara at the Black Sea. The distance between both locations is about 12 $\mathrm{km}$.

Voucher specimens were deposited in the herbarium of the Faculty of Pharmacy, Medical University, Sofia, and identified by Dr. Stefka Dimitrova-Konaklieva.

All samples were investigated microscopically Bacterial or other cells, different from those of the investigated species, were not observed.

\section{Preparation of the extracts}

About $50 \mathrm{~g}$ (dry weight) of each sample were consecutively extracted with $700 \mathrm{ml}$ methanol $700 \mathrm{ml} \mathrm{methanol} /$ chloroform $(1: 1 \mathrm{v} / \mathrm{v})$ and $700 \mathrm{~m}$ chloroform. The extracts were combined and con 
centrated. About $300 \mathrm{ml}$ water was added. The chloroform layer was separated and dried under reduced pressure at $40^{\circ} \mathrm{C}$ yielding $2.9 \mathrm{~g}$ dry wt. The aqueous residue was extracted twice with $300 \mathrm{ml} n$-butanol, that after elimination of solvents the $n$-butanol extract yielded $3.8 \mathrm{~g}$ and the water extract $5.5 \mathrm{~g}$.

\section{Isolation and analysis of sterols}

The chloroform extract of each alga was evaporated under reduced pressure at $40^{\circ} \mathrm{C}$. Part of the dry residue (about $300 \mathrm{mg}$ ) was applied to a silica gel $(30 \mathrm{~g})$ column. The column was eluted with $100 \mathrm{ml}$ petroleum ether, followed by $100 \mathrm{ml}$ petroleum ether/acetone $(15: 1 \mathrm{v} / \mathrm{v}), 100 \mathrm{ml}$ petroleum ether/acetone $(10: 1 \mathrm{v} / \mathrm{v}), 200 \mathrm{ml}$ chloroform, $100 \mathrm{ml}$ chloroform $+1 \%$ methanol, $100 \mathrm{ml}$ chloroform $+3 \%$ methanol, $100 \mathrm{ml}$ chloroform $/$ methanol $(4: 1 \mathrm{v} / \mathrm{v}), 100 \mathrm{ml}$ chloroform/methanol $(3: 1 \mathrm{v} / \mathrm{v})$, $100 \mathrm{ml}$ chloroform/methanol $(1: 1 \mathrm{v} / \mathrm{v}), 200 \mathrm{ml}$ methanol. Fractions containing sterols were identified by thin layer chromatography (TLC). Further purification by prep. TLC on silica gel G (hexane/acetone; 10:1 v/v) was performed. The total sterol mixtures were investigated by GC and GC/MS.

Quantitative analysis was performed on a Pye Unicam 304 gas chromatograph equipped with FID and a capillary column SPB- $1(30 \mathrm{~m} \times$ $0.32 \mathrm{~mm}, 0.25 \mu \mathrm{m}$ film thickness), at $230{ }^{\circ} \mathrm{C}$ and programmed to $300{ }^{\circ} \mathrm{C}$ at $4{ }^{\circ} \mathrm{C} \mathrm{min}-1$ and $10 \mathrm{~min}$ hold. Injector and detector were at $300^{\circ} \mathrm{C}$.

For GC/MS was used a Hewlett Packard 6890 + MS 5973 instrument equipped with a capillary column SPB-50 $(30 \mathrm{~m} \times 0.32 \mathrm{~mm}, 0.25 \mu \mathrm{m}$ film thickness). The MS source was at $250^{\circ} \mathrm{C}$ and the ionisation voltage at $70 \mathrm{eV}$. The $\mathrm{GC}$ oven temperature was at $270^{\circ} \mathrm{C}$ and programmed to $290^{\circ} \mathrm{C}$ at $4^{\circ} \mathrm{C} \min ^{-1}$ and $20 \mathrm{~min}$ hold.

\section{Isolation and analysis of volatiles}

Dry residue of the chloroform extracts $(250 \mathrm{mg}$ from $P$. denudata and $500 \mathrm{mg}$ from $P$. denudata $f$ fragilis) were subjected to a four-hour distillationextraction in a Lickens-Nickerson apparatus. The volatile compounds were extracted from the distillate with diethyl ether (yield: $P$. denudata $8.1 \mathrm{mg}, 3.2 \%$ from the chloroform extract), $P . d e-$ nudata $f$. fragilis $-17.1 \mathrm{mg}, 3.4 \%$ from the chloro- form extract), and investigated by GC/MS equipped with a capillary column HP5-MS (30 $\mathrm{m} \times$ $0.25 \mathrm{~mm}, 0.25 \mu \mathrm{m}$ film thickness), at $40^{\circ} \mathrm{C}$ and programmed to $280{ }^{\circ} \mathrm{C}$ at $6{ }^{\circ} \mathrm{C} \mathrm{min}-1$.

\section{Isolation and analysis of the components of n-butanol extract Isolation of $\alpha$-O-methyllanosol}

Part of the dry $n$-butanol extract from $P$. denudata $f$. fragilis $(0.95 \mathrm{~g})$, dissolved in $\mathrm{MeOH}$ was chromatographed on Sephadex LH-20 column (2 $\times 100 \mathrm{~cm})$ eluted with methanol $\left(2 \mathrm{ml} \cdot \mathrm{min}^{-1}\right)$. The main fraction $(180 \mathrm{mg})$ was identified as 3,4 -dibromo-5-methoxymethyl-1,2-benzenediol ( $\alpha$-Omethyllanosol) (MS, UV, ${ }^{1} \mathrm{H}-\mathrm{NMR}$ and ${ }^{13} \mathrm{C}-\mathrm{NMR}$ spectra identical with literature data) (Kubo et al., 1990).

\section{GC/MS of the n-butanol extract}

$5 \mathrm{mg}$ of each $n$-butanol extracts were subjected to a silylation with $50 \mu \mathrm{l}$ abs. pyridine and $75 \mu \mathrm{l}$ of bis(trimethylsilyl)trifluoroacetamide (BSTFA). The mixtures were heated at $80^{\circ} \mathrm{C}$ for $30 \mathrm{~min}$ and analysed by GC/MS equipped with a capillary column HP-5 (23 m $\times 0.2 \mathrm{~mm}, 0.5 \mu \mathrm{m}$ film $)$ at $100^{\circ} \mathrm{C}$ and programmed to $315^{\circ} \mathrm{C}$ at $5^{\circ} \mathrm{C} \mathrm{min}{ }^{-1}$ and 10 min hold.

\section{Identification of compounds by $G C-M S$ analyses}

The identification was accomplished using computer searches on a NIST98 MS Data library. In some cases, when identical spectra have not been found, only the structural type of the corresponding component was proposed on the basis of its mass-spectral fragmentation. When possible reference compounds were co-chromatographed to confirm GC retention times especially when isomeric compounds have similar spectra.

\section{Antibacterial test}

For the investigation of the antibacterial activity we used a modification of bioautography, recently developed in our laboratory (Kujumgiev et al., 1993). Staphylococcus aureus 209 and Escherichia coli $\mathrm{WF}+$ were used as test microorganisms. For each test $0.5 \mathrm{mg}$ (dry wt.) of each extract was used (chloroform, butanol, water). The samples were dissolved in $0.1 \mathrm{ml}$ ethanol and placed in $25 \mathrm{ml}$ of 
agar in Petri dish with $\mathrm{d}=10 \mathrm{~cm}$. The antibacterial activity was measured by the diameter of the inhibitory zones in the soft agar layer after a 72 $\mathrm{hr}$ incubation at $37^{\circ} \mathrm{C}$. An inhibitory zone with a diameter of less than $10 \mathrm{~mm}$ indicated lack of activity.

\section{Antifungal test}

For the investigations we used the agar cup method (Spooner and Sykes, 1972). Parts of the investigated extracts $(0.5 \mathrm{mg}$ dry wt. dissolved in $0.1 \mathrm{ml}$ ethanol) were placed in a well with a diameter of $10 \mathrm{~mm}, 10^{7}$ cells (Candida albicans 562) were used per Petri dish $(\mathrm{d}=10 \mathrm{~cm})$ with $25 \mathrm{ml}$ of agar. After incubation at $37^{\circ} \mathrm{C}$ for $72 \mathrm{hrs}$ the diameters of the inhibition zones were determined. A diameter of less than $10 \mathrm{~mm}$ indicated lack of activity.

\section{Cytotoxicity assay}

Artemia salina lethality (Solis et al., 1993) was determined using caffeic acid phenethyl ester (CAPE) as active reference substance. Concentrations of 1000, 100, 10 and $1 \mathrm{ppm}$ were used; $10 \mathrm{~A}$. salina per concentration plus control.

\section{Results and Discussion}

\section{Biological activity}

The Gram (+) bacteria Staphylococcus aureus, the Gram (-) bacteria Echerichia coli and the fungi Candida albicans were used for the investigation of the anti-microbial and antifungal activity. The chloroform, $n$-butanol and water fractions, as well as the volatile compounds were tested. The results are reported in Table I. All fractions, except the water extracts from the two algae were active against $S$. aureus. The anti-microbial activity is stronger in $P$. denudata $f$. fragilis. Only the $n$ butanol fraction from $P$. denudata $f$. fragilis showed an activity against $E$. coli. The chloroform, butanol and water fractions from $P$. denudata $f$. fragilis and the butanol extract from $P$. denudata showed an activity against $C$. albicans. The water fraction from $P$. denudata was not active at all and the water fraction from $P$. denudata $f$. fragilis showed an activity only against $C$. albicans. The activity of $\alpha$-O-methyllanosol (one of the important constituents of the $n$-butanol extract of $P$. denudata $f$. fragilis) was also tested. It appears to be
Table I. Antibacterial and antifungal activity of extracts from $P$. denudata and $P$. denudata $f$. fragilis.

\begin{tabular}{llll}
\hline Extracts from: & $\begin{array}{l}\text { Staphylococcus } \\
\text { aureus }\end{array}$ & $\begin{array}{l}\text { Escherichia } \\
\text { coli }\end{array}$ & $\begin{array}{l}\text { Candida } \\
\text { albicans }\end{array}$ \\
\hline
\end{tabular}

P. denudata

Chloroform extract

Diameter of the inhibitory zone $[\mathrm{mm}]^{\mathrm{a}}$

Butanol extract

Water extract

Volatile compounds

$17.3 \pm 0.6$

$22.3 \pm 0.6$

0

$15.3 \pm 0.6$

0

0

0

0

$17.7 \pm 0.6$

P. denudata $f$ fragilis

Chloroform extract

Butanol extract

Water extract

Volatile compounds

$20.7 \pm 1.2$

$24 \pm 1.0$

0

$15.7 \pm 0.6$

$0 \quad 19.7 \pm 0.6$

$14 \pm 0 \quad 18.7 \pm 1.2$

$22.7 \pm 0.6$

$\alpha$-0-Methyllanosol

$27 \pm 1.0$

$16.7 \pm 1.2 \quad 23.3 \pm 1.5$

a Diameter of the inhibition zone less than $10 \mathrm{~mm}$ means absence of activity.

higher than the activity of the total butanol extract.

The cytotoxicity of the extracts was also investigated by using brine shrimp (Artemia salina) test. The results are reported in Table II. The $n$-butanol extract of $P$. denudata $f$. fragilis showed a strong cytotoxic activity.

Table II. Cytotoxicity assay of $P$. denudata and $P$. denudata $f$. fragilis extracts.

\begin{tabular}{ll}
\hline Sample & $\mathrm{LC}_{50}[\mu \mathrm{g} / \mathrm{ml}]$ \\
\hline$P$. denudata & $>1000$ \\
Chloroform extract & $384 \pm 55$ \\
Butanol extract & $>1000$ \\
Water extract & $162 \pm 16$ \\
\hline$P$. denudata f. fragilis & $109 \pm 19$ \\
Chloroform extract & $>1000$ \\
Butanol extract & $60.3 \pm 18$ \\
Water extract & $0.45 \pm 0.5$ \\
\hline$\alpha$-O-methyllanosol & \\
\hline CAPE (standard) &
\end{tabular}

$\mu \mathrm{g}$ is the amount of the dry residue of the extracts.

\section{Investigation of the chloroform extract.}

The chloroform extract was subjected to a further fractionation and two fractions were obtained: sterols (by column chromatography, followed by preparative TLC) and volatile 
compounds (by distillation-extraction in a LikensNickerson apparatus).

\section{Sterol composition}

Sterols are important for the functioning of the cell membranes. Their composition depends on the environment and on the specificity of the organism and in some cases is used for chemotaxonomic investigations. The sterols were investigated by GC/MS (qualitative analysis) and by GC (qualitative and quantitative analyses). The data obtained is reported in Table III. It is evident that the sterol composition of both algae investigated is characteristic for the red algae. Cholesterol, characterised by ${ }^{1} \mathrm{H}-\mathrm{NMR}$, MS and RT, is the main sterol constituent. It is accompanied by low concentrations of other sterols, containing additional double bonds at C-22 and/or alkylation at C-24. ${ }^{1} \mathrm{H}-\mathrm{NMR}$ of the total sterol mixture showed unambiguously that the $\Delta^{22}$-sterols contain only $22 \mathrm{Z}$ double bond. Such unusual sterols were recently found in Black Sea invertebrates (De Rosa et al., 1999; Slantchev et al., 2000). Till now there are no data about the presence of such sterols in algae. There are no significant differences between sterols from $P$. denudata and P.denudata $f$. fragilis. Only one investigation on sterols from Polysiphonia sp. ( $P$. brodiae and $P$. ferulavea) from Qatar (Al Easa et al., 1995) was reported, and their composition strongly differs from those of the Black Sea species. The content of cholesterol was lower in the algae from Qatar, while the alkylated sterols, especially those containing 29 carbon atoms and those with C-22 double bond, were signifi-

Table III. Sterol composition ( $\%$ from the total sterol fraction)*.

\begin{tabular}{|c|c|c|}
\hline Sterols & P. denudata & $\begin{array}{l}\text { P. denudata } \\
\text { f. fragilis }\end{array}$ \\
\hline 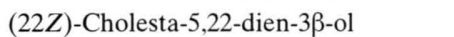 & 0.4 & 0.6 \\
\hline Cholesterol & 83.3 & 80.1 \\
\hline 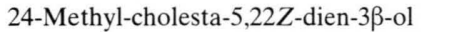 & 3.3 & 0.7 \\
\hline 24-Methyl-cholesta-5,24(28)-dien-3 $\beta$-ol & 1.9 & 3.4 \\
\hline 24-Ethyl-cholesta-5,22Z-dien-3 $\beta$-ol & 0.3 & 0.9 \\
\hline 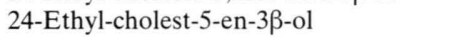 & 0.7 & 0.6 \\
\hline Fucosterol & 0.7 & - \\
\hline
\end{tabular}

* Values obtained from three parallel measurements. The standard deviations (related to peak proportion on the chromatograms) are as follows: \pm 0.3 for cholesterol and \pm 0.1 for the others. cantly higher. Contrary to some other red algae, no $5 \alpha$-stanols were found in the two species analysed. Recently, we found that compared to other Polysiphonia species some constituents of the cell membranes (phospholipids and glycolipids) of $P$. denudata also show significant differences in their composition (Kamenarska et al., 2001). Probably the changes in the environment have a strong effect on the composition of the lipid cell membranes. All investigated Polysiphonia sp. were collected at different locations and that could explain the differences in the cell membrane constituents.

\section{Volatiles}

The volatile constituents, which are a part of the chloroform extract, are of interest because they possess an average antibacterial activity (Table I). It is known that volatile compounds from plants often contain defensive compounds, attractants, repellents, antifeedants, insecticides, etc. There is a limited number of publications on volatiles from algae (Kamenarska et al., 2000, Mahran et al., 1993, Gally et al., 1993) and no investigations on the volatiles from Polysiphonia species. Volatiles from algae are also of importance because they are continually emitted in the atmosphere.

We analysed the volatiles from both algae by GC/MS. The results are summarised in Table IV. The composition of the volatiles was very complex, and there are significant differences between the two samples.

There are a large number of aldehydes in $P$. denudata $f$. fragilis while in $P$. denudata only two aldehydes were found. Some of the aliphatic aldehydes identified were similar to those, forming the so-called "green odour", which attract some pollinators (Wang et al., 1999). Probably such compounds in algae can take part in the relationships between marine organisms.

Hydrocarbons were found in the volatiles of both algae, but their amount was more than twice higher in $P$. denudata. Saturated $n$-paraffins predominated. Heptadecane was the main hydrocarbon in both algae. Low concentrations of three olefins were detected. With the exception of phenanthrene all other hydrocarbons appeared to possess straight chains. Phenanthrene was found in unusually high concentrations for algae. Earlier, a brominated dihydrophenanthrene was found in Polysiphonia ferulaceae (Aknin and Samb, 1992). 
Table IV. Volatile compounds from $P$. denudata and P.denudata $f$. fragilis ( $\%$ from the total volatiles)*.

\begin{tabular}{l} 
Compounds \\
\hline Aldehydes \\
Hexanal \\
2,4-Heptanal \\
Decanal \\
2,4-Decadienal \\
Benzaldehyde \\
Benzeneacetaldehyde
\end{tabular}

Acids
Butanoic acid
Hexanoic acid
Pelargonic acid
Myristic acid
Palmitic acid

Palmitic acid

\begin{tabular}{l}
\multicolumn{1}{c}{ Esters } \\
Benzylbenzoate \\
Isopropylmyristate \\
5-Oxopentanoic acid, methyl ester \\
Pentanedioic acid, dimethyl ester \\
Heptanedioic acid, dimethyl ester \\
9-Oxononanoic acid, methyl ester \\
Octanedioic acid, dimethyl ester \\
Nonadioic acid, dimethyl ester \\
Lauric acid, methyl ester \\
12-Methyltridecanoic acid, methyl \\
ester \\
Myristic acid, methyl ester \\
Pentadecanoic acid, methyl ester \\
16:3 acid, methyl ester \\
(9,12) 16:2 acid, methyl ester \\
16:1 acid, methyl ester \\
16:1 acid, methyl ester (isomer) \\
14-methylpentadecanoic acid, methyl \\
ester \\
Palmitic acid, methyl ester \\
17:0 acid, methyl ester \\
Linolenic acid, methyl ester \\
Linoleic acid, methyl ester \\
18:1 acid, methyl ester \\
18:1 acid, methyl ester (isomer) \\
Stearic acid, methyl ester \\
(7,10,13)20:3 acid, methyl ester
\end{tabular}

Hydrocarbons
Tetradecane
Pentadecane
1-Hexadecene
Hexadecane
1-Heptadecene
Heptadecane
1-Octadecene
Octadecane
Eicosane
Phenantrene

P. denudata $P$. denudata f. fragilis $\mathbf{0 . 1}$

0.1

-

7

-

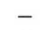

$<0.1$

$-$

10.5

$<0.1$

$<0.1$

$<0.1$

4.6

5.9

2.2

1.0

0.4

$-$

$-$

$-$

-

-

$-$

$-$

0.8

$-$

$-$

$-$

$-$

$-$

$<-\overline{0} 1$

\section{$-$}

\section{$-$}

$-$

$-$
Table IV (continued).

\begin{tabular}{lcc}
\hline Compounds & \multicolumn{2}{c}{ P. denudata $\begin{array}{c}\text { P. denudata } \\
\text { f. fragilis }\end{array}$} \\
\hline $\begin{array}{l}\text { Terpenes } \\
\text { Dihydroactinidiolide }\end{array}$ & $\mathbf{3 . 5}$ & $<\mathbf{0 . 1}$ \\
Isophytol & 0.5 & $<0.1$ \\
$\begin{array}{l}\text { B-Ionone } \\
\text { Farnesylacetone }\end{array}$ & 2.6 & - \\
\multicolumn{1}{c}{ Aromatic compounds } & - & $<0.1$ \\
Phenol & 0.4 & - \\
\hline
\end{tabular}

* The ion current generated depends on the characteristics of the compound and is not a true quantitation. This method is suitable for comparing the chemical composition of different organisms, because the deviations caused by the differences in the intensity of the mass spectral fragmentation will be identical.

Contrary to most of the terrestrial plants where the concentration of terpenoids is high in the volatiles from algae it is low. We found a relatively high concentration of terpenoids in $P$. denudata, while in $P$. denudata $f$. fragilis they were in traces. Dihydroactinidiolode and hexahydrofarnesylacetone are characteristic for most of the marine algae investigated (Kamenarska et al. 2000, Sakagami et al., 1991). $\beta$-Ionone was also found earlier in algae (Rzama et al., 1995). It is a strong deterrent against some insects (Wang et al., 1999) and probably might be active against marine Arthropoda.

We found small amounts of free fatty acids. The free fatty acids are active metabolites. They serve as an important energetic substrate for the cells. Hydrocarbons and free fatty acids, which are common components of the volatiles, often serve as sex pheromones and allelopathic substances (Yasumoto et al., 2000). Very often it is not clear whether they are natural or produced by some hydrolysis during the purification procedures. The method used was a soft one and no hydrolysis occurred, so the acids identified are natural components of the investigated algae. Their concentration and diversity is higher in $P$. denudata.

Phenol was found in low concentrations in the volatiles from $P$. denudata $f$. fragilis. It might be one of the antibacterial constituents. Terpenes and free fatty acids also possess a mild antibacterial activity.

The main components in the volatiles of $P$. denudata $f$. fragilis appeared to be esters. While in $P$. denudata there are only three esters, in $P$. denudata 
f. fragilis there is a large diversity of fatty acid methyl esters (FAME). Although their origin is often disputed (native or artefacts) some of the methyl esters in P. denudata $f$. fragilis, could be of interest, because dioic and oxoacids are rarely found in algae. Two esters of branched fatty acids were detected only in $P$. denudata.

\section{Investigations of polar constituents}

Most of the polar constituents extracted with $n$ butanol possess hydroxyl, amine and carboxyl groups, which determine their polarity. Silylation can transform these compounds into ethers, possessing enough volatility to be investigated by $\mathrm{GC} /$ MS. The results obtained are summarised in Table V.

Acids, carbohydrates and bromine-containing compounds are the main polar constituents in both algae. Monocarboxylic acids (fatty acids and benzoic acid) were present only in $P$. denudata $f$. fragilis, while their oxidised derivatives (polycarboxylic acids and hydroxylated fatty acids) were concentrated almost entirely in $P$. denudata. Probably the enzymes, responsible for the oxidation of the fatty acids are much more active in $P$. denudata than in $P$. denudata $f$. fragilis. Free amino acids predominated in $P$. denudata.

The carbohydrates appeared as a complex mixture in which only glucose and fructose were identified.

Many bromophenols have been previously identified in other algae of the family Rhodomelaceae (Faulkner, 2001; Flodin and Whitfield, 2000).

GC/MS spectra showed the presence of a big number of brominated compounds in both algae investigated. According to their mass spectral fragmentation most of the compounds are bromophenol derivatives of the benzyl alcohol. Such compounds are of interest, because some halogenated compounds possess antibacterial, antifungal, antiviral activities, etc. (Kubo et al., 1990). Other polar components of the investigated algae with antibacterial activity were fatty acids, especially hydroxylated ones and one ester of phosphoric acid.

In order to investigate the composition of the bromine derivatives, we subjected the total butanol extract from $P$. denudata $f$. fragilis to a column chromatography on Sephadex LH-20. One crystal-
Table V. Composition of the n-butanol extracts from $P$. denudata and $P$. denudata $f$. fragilis (\% from the total silylated compounds in the extract)*.

\begin{tabular}{|c|c|c|}
\hline Compounds & P. denudata & $\begin{array}{l}\text { P. denudata } \\
\text { f. fragilis }\end{array}$ \\
\hline Br-containing compounds & 8.8 & 7.3 \\
\hline Monobromo compounds & 1.0 & 0.5 \\
\hline Dibromo compounds & 7.8 & 6.8 \\
\hline Hydroxy acids & 3.7 & 0.3 \\
\hline Hydroxyacetic acid & 0.2 & - \\
\hline 2-Hydroxypropanoic acid & 2.6 & 0.2 \\
\hline 3-Hydroxypropanoic acid & 0.1 & - \\
\hline 2,3-Dihydroxypropanoic acid & 0.7 & 0.1 \\
\hline Hydroxymalic acid & $<0.1$ & - \\
\hline $2,3,4$-Trihydroxybutyric acid & 0.1 & - \\
\hline Polycarboxylic acids & 4.3 & 0.2 \\
\hline 1-Propene-1,2,3-tricarboxylic acid & 2.0 & - \\
\hline Butanedioic acid & 1.6 & 0.1 \\
\hline Citric acid & 0.7 & 0.1 \\
\hline Monocarboxylic acids & - & 1.2 \\
\hline Hexadecanoic acid & - & 0.7 \\
\hline Oleic acid & - & 0.2 \\
\hline Octadecanoic acid & - & 0.1 \\
\hline Benzoic acid & - & 0.2 \\
\hline Amino acids & 2.6 & 0.8 \\
\hline Alanine & 0.1 & - \\
\hline Proline & $<0.1$ & - \\
\hline Glycine & $<0.1$ & - \\
\hline Glutamine & 0.2 & \\
\hline 5-Oxoproline & 2.3 & 0.8 \\
\hline Esters & 1.2 & 0.2 \\
\hline Trimethylphosphate & 0.4 & - \\
\hline $\begin{array}{l}\text { 2,3-Dihydroxyhexadecanoic acid, } \\
\text { propyl ester }\end{array}$ & - & 0.2 \\
\hline $\begin{array}{l}\text { Myristic acid, 2,3-bis-hydroxypropyl } \\
\text { ester }\end{array}$ & 0.8 & - \\
\hline Sugars & 4.3 & 0.6 \\
\hline Glucose & 3.8 & 0.6 \\
\hline Fructose & 0.5 & - \\
\hline Polyols & 1.0 & 0.3 \\
\hline Glycerol & 1.0 & 0.3 \\
\hline$N$-containing compounds & 2.6 & \\
\hline Uridine & 2.4 & - \\
\hline $2 \mathrm{H}$-purin-6-amine & 0.2 & - \\
\hline
\end{tabular}

* The ion current generated depends on the characteristics of the compound and is not a true quantitation.

line substance was isolated. Its mass spectrum was characteristic for a dibromo compound $\left([\mathrm{M}]^{+}\right.$at $310,312,314$, rel. int. ratio $1: 2: 1)$. The ${ }^{1} \mathrm{H}-\mathrm{NMR}$ spectrum showed signals for one aromatic proton ( $\delta 6.94, \mathrm{~s}, 1 \mathrm{H})$, a methoxy group $(\delta 3.32, \mathrm{~s}, 3 \mathrm{H})$ and a benzylic methylene group $(\delta 4.28, \mathrm{~s}, 2 \mathrm{H})$. This data indicated that the compound must be a dibromodihydroxy derivative of benzylmethyl ether. 
After comparison of its MS, UV, ${ }^{1} \mathrm{H}-\mathrm{NMR}$ and ${ }^{13} \mathrm{C}-\mathrm{NMR}$ spectra with literature data (Kubo et al., $1990)$ it was identified as $\alpha$-O-methyllanosol $(3,4-$ dibromo-5-methoxymethyl-1,2-benzenediol). This compound has been found in different Polysiphonia species but not in $P$. denudata (Gribble, 1996). This compound appears to be the main component of the $n$-butanol extract from $P$. denudata $f$. fragilis. $\alpha$-O-methyllanosol is suggested to be a represen-

Al Easa H. S., Kornprobst J. and Rizk A. M. (1995), Major sterol composition of some algae from Qatar. Phytochemistry 39, 373-374.

Aknin M. and Samb A. (1992), Polysiphenol, a new brominated 9,10-dihydronaphtalene from the Senegalese red alga Polysiphonia ferulaceae. Tetrahedron Lett. 33, 555-558.

De Rosa S., Milone A., Popov S. and Andreev S. (1999), Sterol composition of the Black Sea Hydrozoan Obelia longissima (Pallas 1766). Comp. Biochem. Physiol. 123B, 229-233.

Elyakov G. B. and Stonic V. A. (1988), In: Kamernitskii A. V. (Ed.) Steroids from Marine Organisms. Moscow, Nauka [in Russian] pp. 48-57.

Faulkner D. J. (2001), Marine natural products. Nat. Prod. Rep. 18, 1-49, and earlier reviews in the series.

Flodin C. and Whitfield F. (2000), Brominated anisoles and cresols in the red alga Polysiphonia spherocarpa. Phytochemistry 53, 77-80.

Gally A., Yannovits N. and Poulos C. (1993), The aroma volatiles from Cystoseira stricta var. amentaceae. J. Essential Oil Res. 5, 27-32.

Gribble G. W. (1996), Naturally occurring organohalogen compounds-A comprehensive survey. Progress in the Chemistry of Organic Natural Compounds. Herz W., Kirby G. W., Moore R. E., Steglich W. and Tamm Ch. (Eds.). Springer, Publ., Wien, pp. 202-209.

Kamenarska Z., Dimitrova-Konaklieva S., Nikolova Ch., Kujumdjiev A., Stefanov K. and Popov S. (2000), Volatile components of the freshwater algae Spirogira and Mougeotia. Z. Naturforsch. 55c, 495-499.

Kamenarska Z., Stefanov K., Dimitrova-Konaklieva St. and Popov S. (2001), Lipid composition of Polysiphonia denudata (Dillw.) Kutz from the Black Sea. C. r. Acad. bulg. Sci. 54(7), 29-32

Kubo I., Ochi M., Shibata K., Hanke F. J., Nakatsu T., Tan K. S., Taniguchi M., Kamikawa T., Yamagiwa Y., Arizuka M. and Wood W. F. (1990), Effect of a marine algal constituent on the growth of lettuce and rice seedlings. J. Nat. Prod. 53, 50-56.

Kujumgiev A., Bankova V., Ignatova A. and Popov S. (1993), Antibacterial activity of propolis, some of its components and analogs. Pharmazie 48, 785-786. tative of a new class of plant growth regulators showing gibberelin-like activity; and could also be used as an antifouling agent (Kubo et al., 1990).

\section{Acknowledgement}

This research was supported by CNR-Rome and by the Bulgarian National Foundation for Scientific Research (Contract X-710).

Kurbanov I., Gullyev M. N., Tesler I. D., Onov A. and Khekimov Y. K. (1997), Composition and structure of biologically active fatty acids of Caspian Sea algae. Zdravookhr. Turkm. (3), 17-20.

Mahran G. H., Soliman F. M. and El-Kashouy E. A. (1993), Study of volatile constituents of Dictyota dichotoma var. implexa. Indian Perfum. 37, 240-244.

Rzama A., Benharref A., Arreguy B. and Dufourc E. J. (1995), Volatile constituents of green microalgae grown on reused water. Phytochemistry 38, 13751379.

Sakagami H., Iseada J., Fujimori T., Hara Y. and Chihara M. (1991), Volatile constituents of marine green algae. Nippon Suisan Gakkaishi 57, 533-537.

Serkedjieva J., Konaklieva M., Dimitrova-Konaklieva S., Ivanova V., Stefanov K. and Popov S. (2000), Antiinfluenza virus effect of extracts from marine algae and invertebrates. Z. Naturforsch.. 55c, 87-93.

Slantchev K., Stefanov K., Seizova K., Popov S. and Andreev S. (2000), Chemical composition of the lypophylic extract from the tunicate Botryllus schlosseri. Z. Naturforsch. 55c, 794-798.

Solis P., Wright C. W., Anderson M. M., Gupta M. P. and Phillipson J. D. (1993), A microwell cytotoxicity assay using Artemia salina (Brine shrimp). Planta Med. 59, $250-252$.

Spooner F. D. and Sykes G. (1972), Laboratory assessment of antibacterial activity. In: Methods in Microbiology 7B. Norris J. R. and Ribbons D. W. (Eds.). Academic Press, London pp. 216-217.

Usov A. I. and Ivanova A. I. (1987), Polysaccharides of algae XXXVII. Characterization of hybrid structure of substituted $\beta$-agarase and carbon-13-NMR spectroscopy. Bot. Mar. 30, 365-370.

Wang S., Ghisalberti E. L. and Ridsdill-Smith J. (1999), Volatiles from Trifolium as feeding deterents of redlegged earth mites. Phytochemistry 52, 601-605.

Yasumoto M., Mada K., Ooi T. and Kusumi T. (2000), New terpenoid components from the volatile oils of the soft corals Clavularia viridis and Sarcophyton acutangulum. J. Nat. Prod. 63, 1534-1536. 